\title{
O.C.H. [Old China Hand]
}

\author{
Janet Mann
}

YOUR FIRST ARRIVAL at Hong Kong's Kai Tak Airport is a white-knuckle ride, and for once you're grateful you can't see where you're going. If you could share the pilot's view, your eyes would soon close, and your prayers become audible as he seemingly heads straight for the side of one of the dragon mountains that give Kowloon its name. Making a ninety-degree turn and banking hard as he goes, he noses the plane down towards the waters of Victoria Harbour.

In the last few seconds before landing, you find it hard to regain equilibrium as having opened your eyes, loosened your clenched fists and possibly stopped praying, you glance out of the cabin windows and find yourself swooping past apartment windows festooned with washing on bamboo poles, seeing TV aerials and little rooftop sheds. You wonder how the hell people manage to have a life with jet-engines screaming past every four minutes.

Then you're on the ground, and you join in with the applause and appreciative clapping from the other happy passengers and the cabin crew smile happily as they go through final checks before opening doors. You gather your scattered wits along with your hand luggage and follow your fellow travelers out into the bright, bustling, huggermugger welcome of Kai Tak Airport. The heat and humidity hit you, leaving you feeling like you're walking through hot soup, scented with unknown, exciting and ever-so-slightly scary ingredients.

Welcome to Hong Kong.

Voices sing out all around you in a strangely musical language, rising and falling melodically yet punctuated with odd, guttural sounds 
you know you will never completely master however hard you try. You look vaguely around, and someone takes pity, speaks to you in English, points the way to baggage reclaim, and taxi rank, and the haven of your air-conditioned hotel.

Years after, you laugh as guests describe their arrival, and horrify them with tales heard from pilots and air crew about the reason for the enormous checkerboard pattern painted on the concreted slope on the side of a mountain - 'the checkerboard? Oh yes, that's to show the pilots when to turn right so they're in line for the runway ...'

You drive your visitors out along the edge of the harbourside, to the viewing platform set above Sham Shui Po where families picnic on Sunday afternoons, watching the planes land on the air-strip that runs in a straight, impossibly short line below, reaching out into Victoria Harbour. You watch the Star Ferries puttering across the waters between Kowloon and Hong Kong Island, and you see the astonishment on the faces of your friends as they notice how as one plane takes off the next lands, each end of the runway busy in a never-ending cavalcade of arrivals and departures in this city that heads helter-skelter through its days.

And you love every minute of it.

Friends at home ask in astonishment, 'how ever do you cope with all those people? The strange food? The heat? The language?'- coming as you do from a small village where everyone knows everyone else and can probably give you your family tree going back at least four generations. And your answer? There is no answer - you're so caught up in the pace of life, the excitement of finding out how things workor how to make them work, of new experiences, tastes, thoughts even, you simply don't analyse what, or how, or if: you just enjoy each day as it comes, deal with the challenges and frustrations, and get on with the living of it.

It couldn't last, of course. The capacity of Kai Tak, already stretched to the limit simply was not enough as the city grew day by day and the tourists kept coming. As the British Government began, reluctantly, to relinquish its hold on this oriental pearl, it also laid the foundation for a new, improved, immense airport at Chek Lap Kok. Built on an island bulldozed into the sea, surrounded by waters teeming - then - with the spectacular pink dolphins peculiar to the Pearl River Delta, the new airport brought the strengthened links with the Motherland so long awaited by some, so feared by others. It is busy, always, but the bustle 
is missing, somehow sanitised by the acres of gleaming marble floors and smart new shops. In this ultra-modern beehive with worker drone flights landing every couple of minutes, you feel that the welcome, though efficient, streamlined, effective, somehow also runs on the same autopilot system that now lands most of the arriving flights.

At Kai Tak, automated landings were discouraged, and the airport ranked as one of the most challenging amongst pilots and crew. They talk fondly, those who remember, of those white-knuckle days when risks were higher, and rewards more satisfying.

And you? You're getting old too, and settling for a quieter life. But the memories surface now and then, triggered perhaps by the smells wafting from your local Chinese restaurant and takeaway. As you stand, idly waiting for your order of noodles, char siu pork and shrimp dumplings, a sweet heady scent drifts across your nostrils. You look around, searching for the source - and you see it, tucked away at the back of the waiting-area, near the kitchen entrance: a tiny family shrine, painted a rich dark red. An electric candle bulb glows in the alcove, and in front of it sit three oranges piled in a mini pyramid, between three tiny cups holding liquid, probably rice wine. At the side, a tin pot decorated with gaudy scrolls of gold paint, filled with sand and an oddly out-of-place cigarette end, holds three sticks, quietly smouldering amongst the stacks of polystyrene trays and paper napkins.

The smell of joss wafting headily through the room transports you instantly, taking you back thirty years in as many seconds, back to that fragrant harbour you once called home.

Breathe it in. Breathe deep. Enjoy the memories. 